\title{
PENGEMBANGAN MODUL ELEKTRONIK (E-MODUL) BERBASIS FLIPBOOK MAKER UNTUK SUBTEMA PEKERJAAN DI SEKITARKU KELAS IV SD/MI
}

\author{
A.A.M. Maharcika ${ }^{1}$, N.K.Suarni ${ }^{2}$, I.M. Gunamantha ${ }^{3}$ \\ ${ }^{123}$ Program Studi Pendidikan Dasar \\ Universitas Pendidikan Ganesha \\ Singaraja, Indonesia \\ e-mail: agunk.meka@undiksha.ac.id ${ }^{1}$, tut arni@yahoo.com ${ }^{2}$, \\ md gunamantha@yahoo.com ${ }^{3}$
}

\begin{abstract}
Abstrak
Penelitian ini bertujuan untuk mengetahui: 1) validitas modul elektronik (e-modul) pada subtema Pekerjaan di Sekitarku kelas IV SD/MI; 2) kepraktisan modul elektronik (e-modul) untuk subtema Pekerjaan di Sekitarku kelas IV SD/MI. Jenis penelitian ini adalah penelitian pengembangan desain dan produk (Design and Development) dengan merujuk pada model ADDIE. Software yang digunakan untuk mengembangkan modul elektronik (e-modul) adalah Kvisoft Flipbook Maker Pro 3.6.10. Data yang dikumpulkan berupa data validitas modul elektronik (e-modul) dan respon pengguna. Validitas diukur menggunakan uji ahli yang meliputi ahli media, ahli, materi, dan ahli bahasa. Data yang telah terkumpul kemudian dikonversi menggunakan skala likert. Respon pengguna diperoleh dari responden yaitu 2 orang guru dan 40 siswa kelas IV. Hasil penelitian menunjukkan bahwa: 1) uji validitas ahli media, ahli materi, dan ahli bahasa. Rata-rata keseluruhan validasi sebesar $95,56 \%$ yang berada pada interval $81 \%-100 \%$ yang menunjukkan berada pada katagori sangat valid. 2) rata-rata respon guru dan siswa terhadap modul elektronik (e-modul) sebesar $87,19 \%$ berada pada interval $81 \%-100 \%$ dengan kategori sangat praktis. Berdasarkan hasil tersebut dsimpulkan bahwa penelitian ini menghasilkan e-modul yang valid dan praktis.
\end{abstract}

Kata Kunci : E-modul; Kepraktisan; Kvisoft Flipbook Maker; Validitas

\section{Abstract}

This research aims to find out: 1) the validity of the electronic module (e-module) in "Pekerjaan di Sekitarku" sub-theme for grade IV of Elementary School/MI; 2) the practicality of the electronic module user (e-module) to "Pekerjaan di Sekitarku" sub-theme for grade IV of Elementary School/MI. The research method used was a design and product development research (Design and Development) by referring to the ADDIE model. The software used to develop the electronic module (e-module) is Kvisoft Flipbook Maker Pro 3.6.10. The data collected is in the form of electronic module (e-module) validity data and user responses. The validity is measured using an expert test which includes media experts, material experts, and language experts. The collected data was then converted with the use of Likert scale. The respondents were 2 teachers and 40 students of grade IV. The results showed that: 1) the overall average validation conducted by media experts, material experts, and linguists was $95.56 \%$ within the $81 \%-100 \%$ interval which indicates that it is in the very valid category. 2) the average of teacher and student response to the electronic module (e-module) was $88.19 \%$, within the $81 \%-100 \%$ interval in the very practical category. Based on these results, it can be concluded that the e-module developed is valid and practical to users.

Keywords : E-module; Practicality; Kvisoft Flipbook Maker; Validity 


\section{PENDAHULUAN}

Transformasi pendidikan terjadi sejalan dengan perkembangan teknologi yang mencakup berbagai lini kehidupan. Kemajuan ilmu pengetahuan akan berjalan beriringan dengan kemajuan teknologi yang memunculkan berbagai inovasi dan kreasi sehingga memberikan kemudahan dan cara baru bagi manusia dalam melakukan aktivitasnya. Bidang teknologi informasi adalah salah satu bidang yang mengalami lompatan besar dalam inovasi dan kreasi sehingga memberi dampak positif serta cara baru bagi manusia untuk beraktivitas dalam dekade terakhir (Jamun, 2018).

Pada awal tahun 2020, penggunaan TIK semakin meningkat terutama di bidang pendidikan. Hal ini disebabkan dengan status pandemi yang ditetapkan oleh pemerintah akibat munculnya virus Covid-19. Status pandemi ini menyebabkan seluruh sekolah di Indonesia ditutup dan pembelajaran dilakukan secara jarak jauh dengan sistem daring (dalam jaringan). Kegiatan pembelajaran secara daring (dalam jaringan) menuntut kemampuan guru dan siswa dalam penggunaan TIK yang baik sehingga pembelajaran dapat berjalan sesuai dengan harapan.

Proses pembelajaran dengan sistem daring (dalam jaringan) yang saat ini dilakukan di Indonesia khususnya di sekolah dasar menuntut guru untuk dapat berinovasi dalam menyusun dan menyajikan rencana pembelajaran secara digital agar lebih variatif, mampu menarik perhatian, minat, dan memberi semangat belajar siswa untuk mengikuti proses pembelajaran sehingga mampu mengkonstruksi proses belajar menjadi lebih bermakna.

Hal ini mengisyratkan bahwa proses pembelajaran secara daring (dalam jaringan) semakin mengakrabkan guru dan siswa dengan penggunaan perangkat teknologi, seperti: komputer, laptop, maupun gawai yang kesemuanya itu harus ditunjang dengan jaringan internet yang memadai.

Perkembangan kondisi lapangan ini menjadi pelecut inovasi penggunaan TIK perlu dilakukan dalam mengelola pembelajaran di kelas (Yasa, 2018). Selain itu, hal ini semakin menguatkan salah satu prinsip dasar pendidikan yang dicantumkan dalam Permendikbud No. 22/2016 bahwa penggunaan TIK dapat memudahkan pelaksanaan belajar mengajar dan menjadikannya lebih efektif serta efisien. Dengan penggunaan TIK maka proses pembelajaran dapat dilakukan tanpa terhalang ruang dan waktu.

Kondisi di lapangan, banyak guru belum mampu menghadirkan suasana berbeda dalam pembelajaran jarak jauh yang mereka lakukan. Temuan penelitian Arifin (2020), sering kali siswa mengalami kejenuhan dalam mengikuti pembelajaran secara daring yang disebabkan metode mengajar guru yang masih bersifat konvensional dan penggunaan sumber belajar terbatas pada buku teks yang ada. Dalam konsisi ini, seharusnya guru dapat mengembangkan bahan ajar yang dapat diakses secara digital.

Data hasil wawancara terhadap siswa kelas IV SD Negeri 1 Padangsambian menunjukkan bahwa siswa sangat tertarik dengan TIK dan ingin memanfaatkan TIK dalam pembelajaran tetapi tidak mampu dipenuhi oleh guru mereka. Mereka menginginkan bahan ajar tidak hanya berupa bahan cetak tetapi bahan ajar yang lebih menarik, efektif, interaktif, dan berbasis digital.

Siswa saat ini berada pada jaman yang sudah tidak asing lagi dengan teknologi. Kemampuan menggunakan TIK siswa kelas IV SD sudah baik dan mampu menggunakan modul elektronik dalam kegiatan pembelajaran secara mandiri. Oleh karena itu, guru harus mampu menjawab permintaan siswanya dengan cara menyusun bahan ajarnya sendiri sebagai upaya pemenuhan kebutuhan bagi siswanya.

Sudah semestinya, momentum saat ini dapat digunakan guru sebagai ajang untuk meningkatkan kompetensi diri dalam hal transformasi teknologi. Hall (Herawati, 2018) menyatakan bahan ajar merupakan pedoman seorang guru di dalam mengajar baik bentuknya tulisan atau tidak sehingga memudahkannya 
dalam mengajar, sedangkan Pannen (Herawati, 2018) menyatakan bahan ajar merupakan materi pembelajaran yang akan diajarkan dan bentuknya bisa berupa tulisan atau nontulisan yang dibuat secara runtut oleh guru.

Salah satu alternatif untuk mendukung sistem pembelajaran yang bermakna adalah pengembangan modul.

Daryanto, (2014) mengungkapkan bahwa modul merupakan sebuah perangkat bahan ajar yang dibuat dengan terstruktur untuk menciptakan pengalaman belajar mengajar bagi siswa sehingga tujuan belajar yang diinginkan tercapai. Pendapat ini pula didukung oleh (Hamdani, 2011) yang menyatakan modul sebagai sebuah media yang digunakan untuk menyampaikan pelajaran agar siswa bisa belajar mandiri untuk mencapai kompetensi tertentu yang penyusunannya dibuat secara sistematis berupa materi pembelajaran, kegiatan pembelajaran, latihan, dan evaluasi

Seiiring dengan perkembangan teknologi, modul cetak dapat dikonversi ke modul elektronik, yaitu bahan ajar yang disajikan secara runtut, terstruktur, dan interaktif dalam format elektronik berupa tulisan, gambar, gambar bergerak, suara, dan petunjuk sehingga memudahkan penggunanya untuk belajar secara mandiri untuk mencapai tujuan pembelajaran sesuai dengan keinginan (Sugianto, 2013). Selain itu, modul elektronik adalah media pembelajaran berbasis komputer yang memberi kesempatan bagi siswa untuk mengeksplorasi diri dalam menerima pelajaran secara individual dengan cara mengikuti petunjuk program yang digunakan (Arsyad, 2013). Didukung pula temuan Yasa (2018) yang menyatakan bahwa penggunaan modul elektronik (emodul) sangat berkontribusi dalam meningkatkan ketertarikan dan motivasi belajar bagi siswa pada proses pembelajaran. Selain itu, hasil penelitian Kuncahyono (2018) menyatakan tingkat kepraktisan modul elektronik mencapai $86,5 \%$ dengan respon guru dan siswa menunjukkan bahwa modul elektronik (emodul) sangat membantu dalam proses pembelajaran tematik dan modul elektronik (e-modul) dapat digunakan secara mandiri dengan penggunaan peralatan berbasis digital.

Keunggulan modul elektronik antara

lain: mampu menciptakan dan meningkatkan kemampuan siswa untuk belajar mandiri karena modul elektronik terintegrasi dengan teknologi yang mampu menyajikan informasi berupa tulisan, gambar, suara, gambar bergerak, maupun video guna memperjelas materi di dalam modul dan dapat digunakan kapanpun dan di manapun dengan cara mengikuti petunjuk program yang ada di dalam modul elektronik Gunadharma (2011) mengungkapan bahwa modul elektronik mampu menyajikan informasi secara urut dan tersturktur, memberi kesan menarik, serta interaktif sehingga dapat digunakan di mana dan kapan saja secara mandiri dan tidak tergantung pada guru sebagai sumber informasi.

Aplikasi bantuan yang dpat digunakan guru untuk menghasilkan modul elektronik (e-modul) antara lain: $3 D$ Page Flip Professional, Exelearning, Ncesoft Flip Book Maker, Kvisoft Flipbook Maker, dan Flip PDF Professional. Software Kvisoft Flipbook Maker mengkonversi tulisan dalam bentuk PDF menjadi buku elektronik. Pada Kvisoft Flipbook Maker terdapat menu file editing yang berfungsi untuk menambahkan hyperlink, audio, video, gambar, dan objek multimedia ke dalam buku elektronik yang bisa dibaca validnya buku asli. Selain itu, juga terdapat menu design yang berfungsi untuk mengatur background (latar belakang) dengan tema-tema tertentu sehingga menarik saat dibaca.

Pada penelitian ini, peneliti memilih menggunakan Kvisoft Flipbook Maker untuk mengembangkan modul elektronik. Kvisoft Flipbook Maker merupakan aplikasi media interaktif untuk membuat modul elektronik yang dapat menambahkan tulisan, audio, video, dan animasi gerak serta latar belakang yang menjadikan modul lebih menarik dan tidak monoton untuk digunakan dalam proses pembelajaran (Wibowo, 2018). Selain itu, Kvisoft Flipbook Maker juga mampu meningkatkan efektivitas pembelajaran melalui kemampuan berpikir kreatif siswa 
sesuai dengan kurikulum 2013 (Marlina, 2020)

Pada penelitian ini, peneliti berfokus untuk mengembangkan e-modul subtema Pekerjaan di Sekitarku Kelas IV SD/MI berbantuan software Kvisoft Flipbook Maker karena mampu mengubah tampilan pada file PDF seperti buku dalam bentuk digital sehingga pengguna merasa lebih tertarik untuk menggunakannya dengan cara menyisipkan suara, gambar bergerak, video, maupun link internet.

\section{METODE}

Penelitian ini menggunakan metode penelitian dan pengembangan, yaitu sebuah metode penelitian untuk menciptakan suatu produk baru yang di dalamnya terdapat proses pengujian keefektifan terhadap produk yang diciptakan (Sugiyono, 2009).

Rancangan penelitian ini menggunakan model pengembangan ADDIE (Analize, Design, Development, Implementation, Evaluation). Proses validasi produk menggunakan tiga validator, yaitu ahli bahasa, ahli materi, dan ahli media yang bertujuan untuk mengetahui tingkat validitas modul elektronik (e-modul).

Data yang telah dikumpulkan kemudian dianalisis secara deskriptif kualitatif. Modul elektronik (e-modul) yang dihasilkan dikatakan valid apabila memperoleh persentase $\geq 61 \%$. Selanjutnya, dilakukan ujicoba kepada guru dan siswa untuk mendapatkan data respon pengguna modul elektronik yang telah valid. Responden pada ujicoba ini adalah 2 orang guru kelas IV SD/MI dan 40 orang siswa kelas IV SD/MI. Modul elektronik (e-modul) yang dihasilkan dikatakan praktis apabila memeroleh persentase $\geq 61 \%$.

\section{HASIL DAN PEMBAHASAN}

Penelitian ini difokuskan untuk mengembangkan bahan ajar berupa modul elektronik (e-modul) pada subtema Pekerjaan di Sekitarku Kelas IV SD/MI berbantuan aplikasi Kvisoft Flipbook Maker. Kvisoft Flipbook Maker merupakan aplikasi media interaktif untuk membuat modul elektronik yang dapat menambahkan tulisan, audio, video, dan animasi gerak serta latar belakang yang menjadikan modul lebih menarik dan tidak monoton untuk digunakan dalam proses pembelajaran (Wibowo, 2018).

Selain itu, Kvisoft Flipbook Maker juga mampu menghasilkan modul elektronik yang dapat dibaca secara bolak-balik validnya buku asli (Ihsan, 2014). Proses validasi modul elektronik dilakukan berdasarkan instrumen penilaian yang sudah dibuat sebelumnya dan berfungsi untuk mengukur tingat validitas modul elektronik sebelum dilakukan uji lapangan. Proses validasi modul elektronik (e-modul) menggunakan 3 validator, yaitu ahli bahasa, ahli materi, dan ahli media. Hasil validasi modul elektronik (e-modul) pada Subtema Pekerjaan di Sekitarku disajikan pada Tabel 1 berikut

Tabel 1. Rata-Rata Keseluruhan Validasi Modul Elektronik

\begin{tabular}{ccccc}
\hline $\begin{array}{c}\text { Rata-rata skor } \\
\text { ahli media }\end{array}$ & $\begin{array}{c}\text { Rata-rata skor ahli } \\
\text { materi }\end{array}$ & $\begin{array}{c}\text { Rata-rata skor ahli } \\
\text { bahasa }\end{array}$ & $\begin{array}{c}\text { Rata-rata } \\
\text { keseluruhan }\end{array}$ & Kriteria \\
\hline $92,96 \%$ & $94,84 \%$ & $98,89 \%$ & $95,56 \%$ & $\begin{array}{c}\text { Sangat } \\
\text { valid }\end{array}$ \\
\hline
\end{tabular}

Berdasarkan hasil perhitungan pada Tabel 1, rata-rata keseluruhan validasi sebesar $95,56 \%$ dan berada pada interval $81 \%-100 \%$ dengan kriteria sangat valid. Ini menunjukkan bahwa modul elektronik (e-modul) secara konten meliputi materi, media, dan bahasa sudah valid untuk digunakan pada tahap selanjutnya, yaitu ujicoba pada guru dan siswa untuk mengukur kepraktisan modul elektronik (e-modul).

Modul elektronik yang telah divalidasi kemudian diperbaiki sesuai masukan validator dan diujicobakan kepada 2 orang guru dan 40 orang siswa kelas IV SD Negeri 1 Padangsambian. 
Guru akan memberikan respon terhadap aspek kemenarikan produk, kemudahan penggunaan produk, dan manfaat produk. Sedangkan siswa akan memberikan respon terhadap aspek ketertarikan, materi, dan bahasa. Hasil respon guru dan siswa terhadap modul elektronik (emodul) dapat dilihat pada Tabel 2 berikut.

Tabel 2. Hasil Penilaian Respon Guru Terhadap Modul Elektronik

\begin{tabular}{cccc}
\hline $\begin{array}{c}\text { Rata-rata skor } \\
\text { respon guru }\end{array}$ & $\begin{array}{c}\text { Rata-rata skor respon } \\
\text { siswa }\end{array}$ & Rata-rata keseluruhan & Kriteria \\
\hline $86,25 \%$ & $88,13 \%$ & $87,19 \%$ & Sangat praktis \\
\hline
\end{tabular}

Berdasarkan Tabel 2 diperoleh ratarata respon guru dan siswa terhadap modul elektronik (e-modul) sebesar $87,19 \%$ dan berada pada interval $81 \%$ $100 \%$ yang menunjukkan modul elektronik (e-modul) berada pada katagori sangat praktis.

Hasil pengembangan dari penelitian ini adalah modul elektronik (e-modul) berbasis flipbook maker untuk subtema Pekerjaan di Sekitarku Kelas IV SD/MI yang dikembangkan menggunakan model pengembangan ADDIE dengan uraian sebagai berikut.

Pertama, Analysis (analisis). Pada tahap analisis, peneliti menganalisis kebutuhan dengan cara mewawancarai siswa kelas IV SD Negeri 1 Padangsambian. Data yang diperoleh adalah guru sudah memanfaatkan TIK dalam pembelajaran yang dilakukan. Guru menggunakan Whats App sebagai media pembelajaran dalam memberikan materi ajar tetapi bahan ajarnya bersifat konvensional karena masih menggunakan buku paket dan buku LKS terbitan penerbit. Selain itu, didapatkan pula data tentang siswa merasa bosan di dalam pembelajaran karena terkesan monoton. Siswa ingin menggunakan bahan ajar berbasis TIK karena dalam keseharian mereka sudah terbiasa menggunakan handphone, laptop, dan internet.

Analisis juga dilakukan terhadap buku pegangan guru dan siswa Subtema
Pekerjaan di Sekitarku revisi 2017 untuk mengetahui pemetaan kompetensi inti dan kompetensi dasar pada subtema tersebut sehingga peneliti dapat menyusun materi yang sesuai dengan kompetensi dasar tersebut.

Kedua, Design (Desain). Pada tahap ini, peneliti merancang modul elektronik (e-modul) pada Subtema Pekerjaan di Sekitarku Kelas IV SD/MI, meliputi: 1) Kerangka modul elektronik, dibuat berdasarkan Panduan Pengembangan Bahan Ajar Depdiknas. 2) Mendesain isi pembelajaran, antara lain: informasi pendukung pencapaian KD, kegiatan siswa untuk pencapaian KD, mencari video pendukung materi pembelajaran, dan pada bagian akhir berisi rangkuman dan evaluasi serta kunci jawaban.

Inti modul elektronik ini adalah materi (konten). Pada bagian ini berisi informasi pendukung dan kegiatan belajar yang menyesuaikan dengan kompetensi dasar yang ada. Informasi dan kegiatan pembelajaran dirancang secara terorganisir dan menggunakan kalimat yang mudah dimengerti siswa sehingga setelah mempelajari modul elektronik tersebut maka tujuan yang telah dirumuskan dapat tercapai. Tampilan materi pada modul elektronik Subtema Pekerjaan di Sekitarku Kelas IV SD/MI terlihat pada Gambar 1 berikut. 


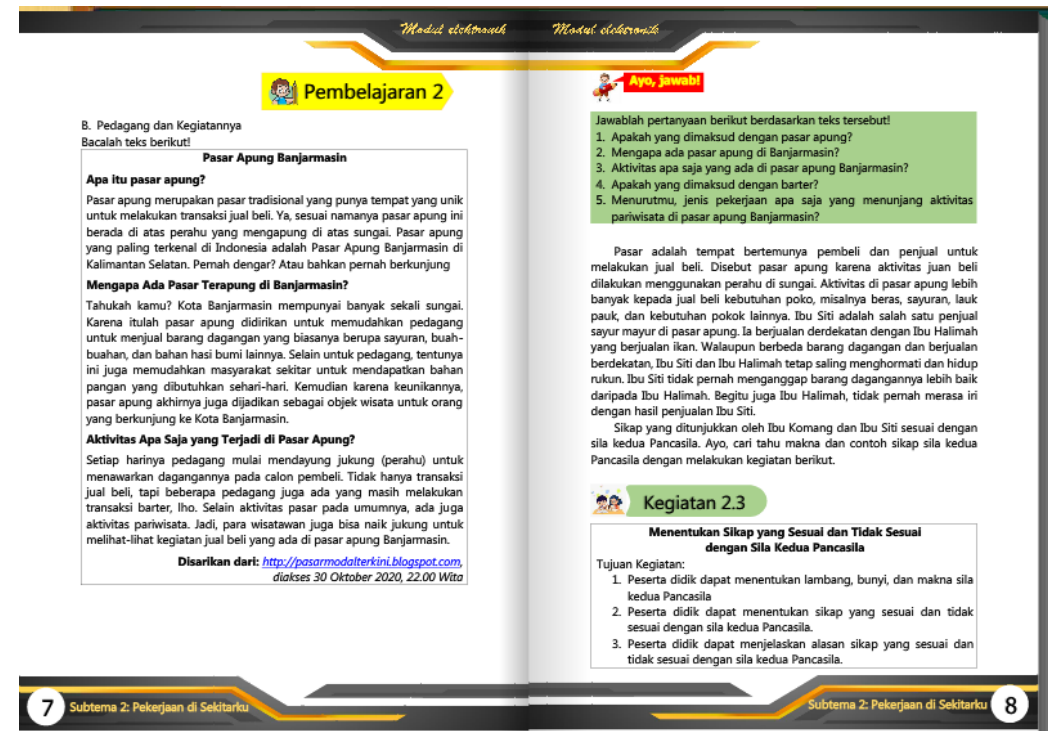

Gambar 1. Materi Modul Elektronik

Selain itu, peneliti juga merancang instrumen untuk mengukur validitas modul elektronik (e-modul). Instrumen yang dirancang dalam bentuk angket dengan skala Likert 5 jawaban, yaitu Sangat Kurang (SK), Kurang (K), Cukup (C), Baik (B), dan Sangat Baik (SB). Jawaban tersebut akan dikonversi ke dalam skor 1 , 2, 3, 4, dan 5 sesuai dengan urutan jawaban.

Butir-butir instrumen penilaian validitas modul elektronik (e-modul) disusun berdasarkan pedoman Depdiknas, meliputi validitas kegrafikan, validitas bahasa, validitas isi, dan validitas penyajian. Proses validasi validitas modul elektronik dilakukan 3 ahli, yaitu ahli media, ahli materi, dan ahli bahasa. Penilaian ahli media dilakukan berdasarkan 27 butir pertanyaan tentang validitas kegrafikan, penilaian ahli bahasa dilakukan berdasarkan 9 butir pertanyaan tentang validitas bahasa yang digunakan, dan penilaian ahli materi dilakukan berdasarkan 31 butir pertanyaan tentang validitas isi, penyajian, dan bahasa.

$$
\text { Ketiga, }
$$

Development (Pengembangan). Tahap pengembangan terdiri dari dua langkah, yaitu pengembangan modul elektronik (emodul) dan penilaian modul elektronik (emodul). Pengembangan modul elektronik meliputi pengembangan font dan warna pada modul elektronik.
Huruf (font) merupakan elemen penting karena memiliki karakteristik dan makna yang berbeda (Syahrul, 2019). Font Sans Serif adalah desain huruf tanpa garis kait yang efisien, praktis, dan modern (Kusrianto, 2010). Contoh font Sans Serif adalah Impact dan Segoe UI. Font Impact digunakan pada sampul modul elektronik dan font Segoe UI digunakan pada bagian isi modul. Berikut adalah tampilan jenis font Impact dan font Segoe UI.

ABCDEFGHIJKLMNOPORSTUWWXYZ ahcefefghijklmnopurstuwwxyz 1234567890

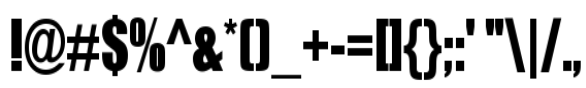

Gambar 2. Font Impact abcdefghijklmnopgrsturwxyz ABCDEFGHIJKLMNOPQRSTUVWXYZ

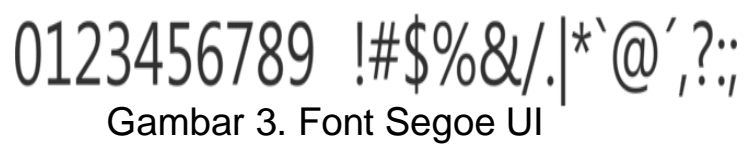

Warna sangat berperan dalam menempatkan dan menanamkan basis pengetahuan pada anak sehingga mudah diterima (Nurdini, 2018). Inovasi dapat dilakukan anak berdasarkan analisis 
kepekaannya terhadap warna suatu objek (Sahar, 2014). Goethe dan Itten (Yogananti, 2015) menyatakan bahwa warna memberikan efek atau kesan dan pengaruh terhadap emosi manusia yang disebut dengan psikologi warna. Psikologi warna Goethe dan Itten dapat dilihat pada tabel 3 dan 4 berikut.

Tabel 3. Psikologi Warna Goethe

\begin{tabular}{|c|c|c|c|}
\hline Warna & Kesan Positif & Kesan Negatif & $\begin{array}{c}\text { Pengaruh terhadap } \\
\text { Manusia }\end{array}$ \\
\hline Merah & Bermartabat & & $\begin{array}{l}\text { Memberi kesan } \\
\text { semangat }\end{array}$ \\
\hline Kuning & Ceria dan cepat & $\begin{array}{l}\text { Tidak } \\
\text { menyenangkan }\end{array}$ & $\begin{array}{l}\text { Memberi kesan } \\
\text { sukacita }\end{array}$ \\
\hline Biru & Warna yang menyenangkan & $\begin{array}{l}\text { Melankolis, dingin, } \\
\text { dan gelisah }\end{array}$ & Memberi kesan sedih \\
\hline Jingga & $\begin{array}{l}\text { Gembira, suka cita, hangat, } \\
\text { hidup, dan passion yang } \\
\text { tinggi }\end{array}$ & Menjengkelkan & $\begin{array}{l}\text { Memberi kesan } \\
\text { sukacita }\end{array}$ \\
\hline Ungu & Aktif & Rentan dan cemas & Memberi kesan sedih \\
\hline Hijau & Tenang & & $\begin{array}{l}\text { Memberi kesan } \\
\text { tenang }\end{array}$ \\
\hline
\end{tabular}

Tabel 4. Psikologi Warna Itten

\begin{tabular}{cl}
\hline Warna & Pengaruh terhadap emosi \\
\hline Merah & Memberi kesan kuat \\
Kuning & Memberi kesan ceria \\
Biru & Memberi kesan yakin \\
Jingga & Memberi kesan sombong \\
Ungu & Memberi kesan suci \\
Hijau & Memberi kesan kasih sayang \\
\hline
\end{tabular}

Pemilihan dominasi warna merah pada sampul modul elektronik mencirikan kekuatan dan martabat modul elektronik. Sampul juga dilengkapi dengan gambar yang mencirikan isi modul elektronik.
Penggunaan warna hijau pada wacana modul elektronik memberi kesan nyaman pada saat siswa membaca modul elektronik. Berikut ini adalah tampilan sampul modul elektronik.

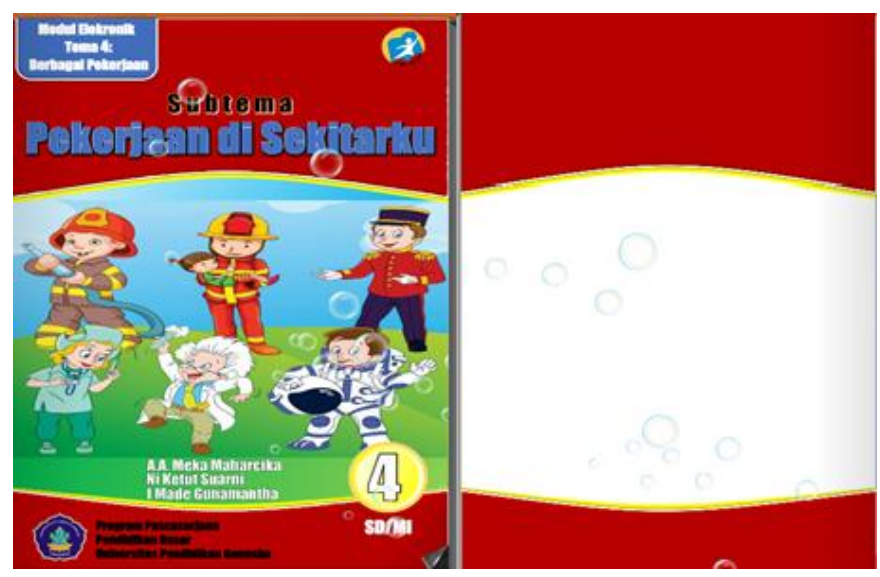

Gambar 4. Sampul Modul Elektronik

Pada tahap ini juga dilakukan validasi modul elektronik oleh para ahli. Berdasarkan hasil perhitungan pada Tabel
1 diperoleh rata-rata keseluruhan validasi sebesar $95,56 \%$ dan berada pada interval $81 \%-100 \%$ dengan kriteria sangat valid. 
Berdasarkan catatan ahli, terdapat beberapa saran perbaikan yang diberikan untuk menyempurnakan modul elektronik (e-modul). Adapun perbaikan yang dilakukan adalah sebagai berikut.

Pertama, penggunaan konten berbasis kearifan lokal. Sebelumnya penulis menggunakan wacana Kedo-Kedo di Wakatobi sehingga diberikan saran diganti dengan penangkapan ikan dengan bubu di Bali. Berdasarkan saran tersebut, peneliti telah mengganti wacana tersebut dengan berbasis lokal. Perbaikan wacana dapat dilihat pada Tabel 5 berikut.

Tabel 5. Perbaikan Wacana Berbasis Lokal

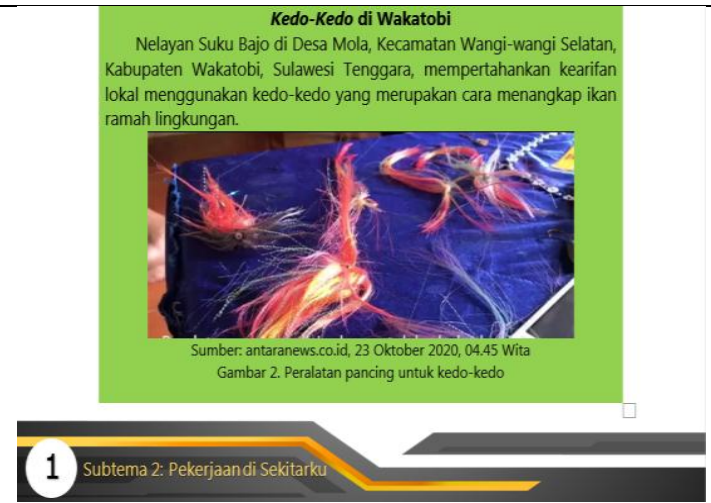

Tampilan sebelum revisi

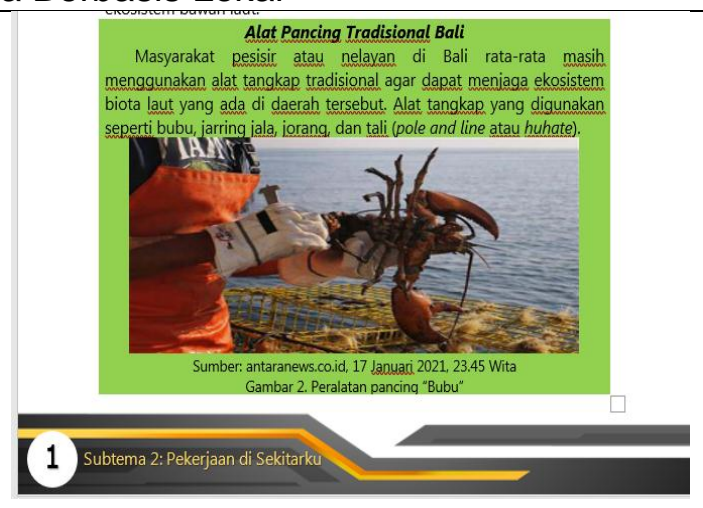

Tampilan sesudah revisi
Penggunaan desain pembelajaran berbasis kearifan lokal memberi implikasi terhadap kebermaknaan belajar. Hal ini sesuai penelitian Chofifah (2019) bahwa budaya daerah dapat diterapkan pada desain pembelajaran tematik integratif dan memberikan peningkatan hasil dan kemampuan belajar di kelas IV SDN Salatiga 03. Hal ini senada dengan penelitian Widiastuti dan Purnawijaya (2019) yang memperlihatkan adanya peningkatan hasil belajar dan kebermaknaan belajar menggunakan desain pembelajaran berbasis budaya lokal siswa kelas 4 SD No 2 Sesetan.
Kedua, kegiatan belajar secara berkelompok. Peneliti merancang beberapa kegiatan belajar secara berkelompok sehingga mendapat saran dari ahli bahwa modul digunakan untuk kegiatan belajar mandiri sedangkan di dalam modul ada tugas yang dikerjakan secara berkelompok. Perlu dipertimbangkan lagi cara/teknis siswa mengerjakan tugas secara kelompok. Berdasarkan saran ahli, maka penulis mengubah kegiatan belajar berkelompok menjadi kegiatan belajar mandiri. Perbaikan tersebut terlihat pada Tabel 6 berikut.

Tabel 6. Perbaikan Kegiatan Belajar Siswa

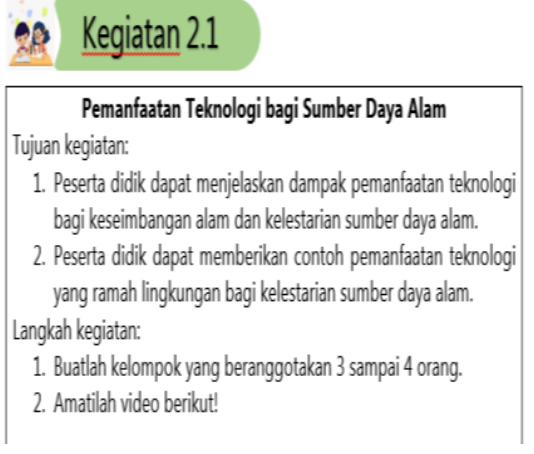

Kegiatan pembelajaran sebelum revisi

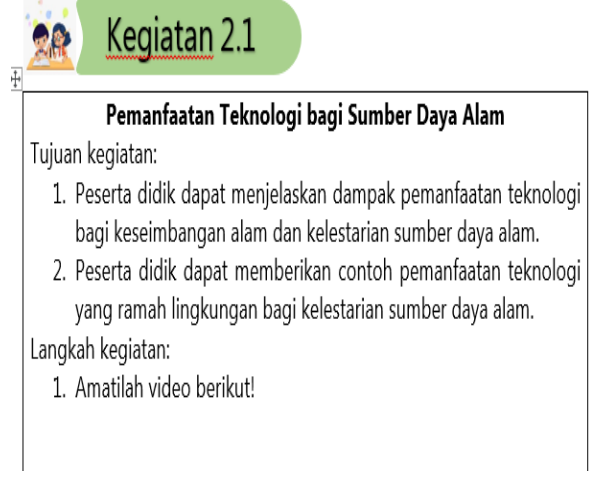

Kegiatan pembelajaran setelah revisi 
Ketiga, penambahan halaman glosarium. Pada modul yang dikembangkan sebelumya tidak terdapat glosarium sehingga mendapat saran dari ahli untuk menambahkan halaman glosarium setelah daftar pustaka pada modul elektronik. Berdasarkan saran ahli tersebut, peneliti menambahkan halaman glosarium setelah daftar pustaka.

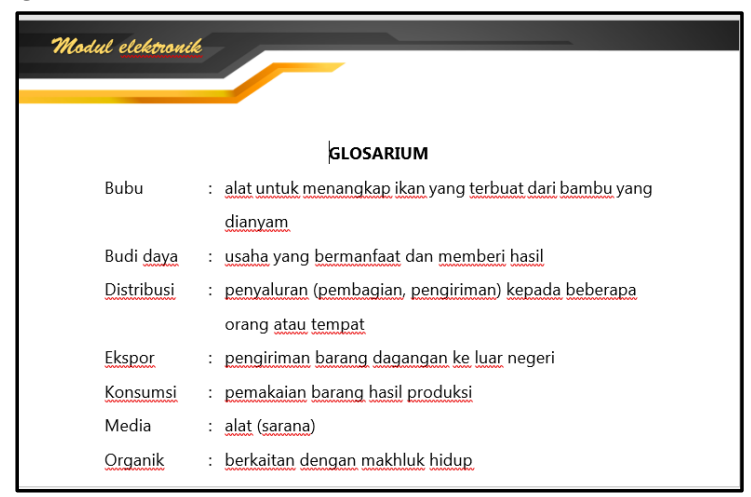

Gambar 5. Penambahan Halaman Glosarium

Pada modul elektronik, penggunaan bahasa menurut ahli sudah sangat valid. Dalam modul elektronik terdapat beberapa penggunaan tanda baca yang belum lengkap. Sehingga disarankan untuk memperbaiki tanda baca dan telah diperbaiki oleh peneliti.

Setelah dilakukan perbaikan, modul elektronik (e-modul) kemudian diujicoba kepada guru dan siswa untuk mengetahui kepraktisan modul elektronik yang dikembangkan. Berdasarkan hasil analisis data, diperoleh rata-rata respon guru dan siswa terhadap modul elektronik (e-modul) sebesar $87,19 \%$ berada pada interval $81 \%-100 \%$ dengan kategori sangat praktis.

\section{PENUTUP}

Penelitian ini mengembangkan modul elektronik (e-modul) dengan model ADDIE. Prosedur pengembangan modul elektronik ini, yaitu: (1) Analysis, (2) Design, (3) Development, (4) Implementation, dan (5) Evaluation atau evaluasi.

Berdasarkan uji validitas oleh para ahli diperoleh rata-rata keseluruhan sebesar $95,56 \%$ yang berada pada interval $81 \%-100 \%$ sehingga modul elektronik (e-modul) memiliki kriteria sangat valid. Selain itu, rata-rata respon guru dan siswa terhadap modul elektronik (e-modul) sebesar $87,19 \%$ berada pada interval $81 \%-100 \%$ dengan kategori sangat praktis.

Berdasarkan simpulan, saran peneliti sebagai berikut.

1. Guru atau peneliti lain dapat melakukan penelitian lanjutan terkait efektifitas modul elektronik mengingat pengembangan modul elektronik ini hanya sampai tahap development yaitu, uji validitas dan kepraktisan modul elektronik.

2. Temuan dalam penelitian ini diharapkan dapat menjadi rujukan kepala sekolah untuk memotivasi kreativitas guru dalam merancang pembelajaran dan bahan ajar sehingga hasil pembelajaran menjadi lebih optimal.

3. Hasil penelitian ini dapat dijadikan acuan pemerintah dalam pengembangan bahan ajar yang dapat mengakomodasi pembelajaran dalam jaringan (daring) sebagai bentuk adaptasi pembelajaran di era 4.0

\section{DAFTAR RUJUKAN}

Arifa, F. N. (2020). Tantangan Pelaksanaan Kebijakan Belajar Dari Rumah Dalam Masa Darurat Covid19. Info Singkat; Kajian Singkat Terhadap Isu Aktual Dan Strategis, XII(7/I), 6. http://berkas.dpr.go.id/puslit/files/info singkat/Info Singkat-XII-7-IP3DIApril-2020-1953.pdf

Arsyad, A. (2013). Media Pembelajaran. Jakarta: PT Raja Grafindo Persada.

Chofifah, Nur., Stefanus C. Relmasira \& Feprina Pinda Pratami (2019). Desain Pembelajaran Tematik Integratif Berbasis Budaya untuk Meningkatkan Hasil dan Kebermaknaan Belajar. Jurnal Penelitian Humaniora Vo. 20 No 01, $39-46$

Gunadharma, A. (2011). Pengembangan Modul Elektronik sebagai Sumber Belajar untuk Mata Kuliah Multimedia Design. Jurnal 
Pendidikan Teknoogi dan Kejuruan, 3.

Hamdani. (2011). Strategi Belajar Mengajar. Bandung: Pustaka Setya.

Herawati, N. S., \& Muhtadi, A. (2018). Pengembangan Modul Elektronik (EModul) Interaktif Pada Mata Pelajaran Kimia Kelas XI SMA. Jurnal Inovasi Teknologi Pendidikan Vol 5 No 2, 180-191.

Janum, YM. 2018. Dampak Teknologi Terhadap Pendidikan. Tersedia pada Jurnal Pendidikan dan Kebudayaan Missio, Volume 10, Nomor 1, Januari 2018, hlm. 1-136

Korur, Fikret, Sacip Toker, \& Ali Eryılmaz. 2016. Effects of the integrated online advance organizer teaching materials on students' science achievement and attitude. Journal of Science Education and Technology. 25(4):628-640

Kuncahyanto. (2018). Pengembangan EModul (Modul Digital) dalam Pembelajaran Tematik di Sekolah Dasar. JMIE: Journal of Madrasah Ibtidaiyah Education, 2(2), 219-231

Kusrianto, A. 2010. Pengantar Tipografi. Jakarta: PT Elex Media Komputindo

Marlina. (2020). Pengembangan Modul Elektronik Pembelajaran IImu Pengetahuan Sosial Berbasis Etnokonstruktivisme Dalam Topik Lacak dan Tengkuluk Menggunakan Aplikasi Kvisoft Flipbook Maker Untuk Kelas V Sekolah Dasar. Repository https://repository.unja.ac.id/

Nurdini. (2018). Implemantasi Warna pada Sampul Buku Cerita Bergambar Legenda Ciujung dan Ciberang. Visual Heritage: Jurnal Kreasi Seni dan Budaya Vol 01 No 01, 69-77
Sahar, S., \& Rohita, R. (2014). Meningkatkan Kemampuan Mengenal Warna dengan Metode Eksperimen di Kelompok Anak Usia 3-4 Tahun di PPT Flamboyan RW II. PAID. Teratai, 3(3), 1-6

Sugianto, D. (2013). Pengembangan Modul Elektronik Fisika dengan Strategi PDEODE pada Pokok Bahasan Teori Kinetik Gas untuk Siswa Kelas XI SMA. Invotec Vol IX No 2, 110-116.

Sugiyono. (2009). Metode Penelitian Pendidikan Pendekatan Kuantitatif, Kualitatif, dan R \& D. Bandung: Alfabeta.

Wibowo., E. P. (2018). Pengembangan Media Flash Flipbook Untuk Meningkatkan Keterampilan Berfikir Kreatif Siswa Dalam Pembelajaran IPA di SMP. Jurnal Matematika, 147-156.

Widiastuti, Ni Luh Gede Karang \& I Putu Edy Purnawijaya. 2019. Penerapan Pembelajaran Tematik Berbasis Kearifan Lokal untuk Meningkatkan Hasil dan Kebermaknaan Belajar. Seminar Nasional INOBALI Inovasi Baru dalam Penelitian Sains, Teknologi, dan Humaniora, 11031110.

Yasa, Arnelia Dwi. (2018). E-Module Based on Ncesoft Flip Book Maker for Primary School Students. International Journal of Engineering \& Technology, 7(3.4)

Yogananti, Auria Farantika. (2015). Pengaruh Psikologi Kombinasi Warna dalam Webite. Andharupa, Jurnal Desain Komunikasi Visual \& Multimedia Vol 01 No 01, 45-54 